https://helda.helsinki.fi

\title{
A framework for identifying cross-border impacts of climate change on the energy sector
}

\section{Groundstroem, Fanny Marie}

2019

Groundstroem , F M \& Juhola , S K 2019 , ' A framework for identifying cross-border impacts of climate change on the energy sector ', Environment Systems and Decisions, vol. 39 , pp. 3-15 . https://doi.org/10.1007/s10669-018-9697-2

http://hdl.handle.net/10138/309080

https://doi.org/10.1007/s10669-018-9697-2

acceptedVersion

Downloaded from Helda, University of Helsinki institutional repository.

This is an electronic reprint of the original article.

This reprint may differ from the original in pagination and typographic detail.

Please cite the original version. 


\title{
A framework for identifying cross-border impacts of climate change on the energy sector
}

\author{
Authors: Fanny Groundstroem ${ }^{1}$, Sirkku Juhola $^{1}$ \\ ${ }^{1}$ Department of Environmental Sciences, University of Helsinki, Viikinkaari 2A, P.O. Box 65, 00014, \\ Helsinki, Finland \\ Corresponding author: Fanny Groundstroem. E-mail: fanny.groundstroem@helsinki.fi. Phone no:
}

+358408219149. Orchid ID 0000-0002-7589-1341

\begin{abstract}
This paper presents a conceptual framework based on a supply chain approach and a statistical index to identify potential cross-border impacts on the current energy systems of the Nordic countries. Three examples illustrate the usability of the framework and highlight the significance of cross-border impacts for different segments of the energy sector. Additionally, the incorporation of cross-border impacts within Nordic climate assessments and adaptation policies are assessed by reviewing governmental reports and documents. Findings show that all the Nordic countries are vulnerable to various degrees to potential cross-border impacts, due to their energy sectors being highly globalised and interconnected. Nodes of vulnerability exist in both import and export supply chains, as well as through the global context. However, cross-border impacts are not yet properly included in Nordic climate assessments or energy strategies. This paper can assist policy makers and energy planners in making comprehensive vulnerability assessments that address both domestic and international climate risks.
\end{abstract}

Keywords: climate and energy policy, climate change adaptation, climate change risk assessment, supply chain management, Nordic countries 


\section{Introduction}

While it is generally agreed that mitigation is a global issue, adaptation action has mostly been perceived as locationspecific (Huitema et al. 2016), mainly considering direct impacts of climate change stemming from projected changes in the local climate of an area. This fails to account for the fact that the world is highly globalised, with interconnections and interdependencies between nations, societies and sectors, which create a layer of risk that can result in unexpected consequences (Arnell et al. 2016; Oppenheimer et al. 2014). These interconnections may be related to global trade markets for food or commodities (e.g. Bren d'Amour et al. 2016), the global financial market (e.g. Schenker 2013), migration and international security (e.g. King et al. 2015), globalisation and land-use change (e.g. Meyfroidt et al. 2013), health issues (e.g. Adger et al. 2009), or cross-sectoral interactions (Harrison et al. 2016; Kebede et al. 2015). Therefore, also crossborder impacts brought about by climate change induced events outside the study area need to be considered in adaptation assessments (Dzebo and Stripple 2015).

However, according to Hallegatte et al (2011), analyses of climate change impacts, adaptation options and vulnerabilities often fail to account for interactions of impacts among regions. This is confirmed by Perdinan and Winkler (2014), who identified a lack of integration of spatial linkages and interactions as one of the main shortcomings in climate assessments. The slow onset of research on cross-border impacts is probably due to the complexity of interactions that need to be analysed, the absence of conceptual clarity, lack of methodological tools and the difficulty in obtaining relevant data. It is important to recognise that cross-border impacts are often inadvertently brought about by mitigation (e.g. biofuel production) and adaptation actions (e.g. migration or land-use change) (Bradley et al. 2012) in other regions, nations or sectors (Oppenheimer 2013), accentuating the need for cross-sectoral and transboundary collaboration in climate risk management and adaptation.

The energy sector is especially globalised and interconnected (Goldthau 2011), making it inherently vulnerable to crossborder impacts of climate change. However, within the energy sector, climate change mitigation has received much more attention than adaptation (Ebinger and Vergara 2011; Mideksa and Kallbekken 2010), due to around 60\% of total global anthropogenic greenhouse gas (GHG) emissions being attributed to the burning of fossil fuels (Bruckner et al. 2014). Additionally, there are as yet no frameworks that assess cross-border impacts of climate change on the energy sector, as previous impact assessments have been confined to national borders (see e.g. Wilbanks et al., 2014).

This paper presents a framework to conceptualise cross-border impacts of climate change on the energy sector, and identifies and compares nodes of vulnerability to cross-border impacts within energy supply chains of the Nordic countries. The paper advances the research on cross-border impacts and highlights the importance of including them in 
climate research and assessments. The Nordics were chosen as the study region because of their highly international economies and globalised energy sectors, making them potentially vulnerable to cross-border impacts of climate change (Benzie et al. 2016). Furthermore, security of energy supply is highly important for the Nordics, due to a cold climate, energy intensive industries and a high standard of living resulting in high energy use per capita (OECD/IEA 2016). This paper shows that despite the significance that cross-border impacts may have for these countries, they are not properly accounted for in energy and climate policies, with potentially harmful consequences.

\section{Background and previous research}

\subsection{Terminology and previous research of cross-border impacts}

Due to the fact that cross-border impacts have only been acknowledged in the literature fairly recently, clarity in terminology is still lacking, which further adds to the difficulty of studying cross-border impacts. A number of different terms, concepts and definitions have been proposed and used in different contexts (Table 1).

Table 1. Different terms used to describe cross-border impacts brought about by climatic, environmental or societal change.

\begin{tabular}{|c|c|c|}
\hline Term used & Field of study & Definition \\
\hline Cascading risk & Global governance & Risks that spread over large distances and cause global crises \\
\hline Connected risk & Global governance & $\begin{array}{l}\text { "Changing risks in one domain [...], can affect risks in another domain" } \\
\text { (Galaz et al. 2014) }\end{array}$ \\
\hline $\begin{array}{l}\text { Distal } \\
\text { interconnection }\end{array}$ & $\begin{array}{l}\text { Social ecology, land-use } \\
\text { change }\end{array}$ & Connection between distant places (see e.g. Meyfroidt et al. 2013) \\
\hline Indirect impact & Climate change adaptation & $\begin{array}{l}\text { "Impacts that are observed or expected in one place, but are brought about by } \\
\text { climate change or extreme events somewhere else" (Benzie et al. 2013) (see } \\
\text { also Kebede et al. 2015) }\end{array}$ \\
\hline $\begin{array}{l}\text { International } \\
\text { impact }\end{array}$ & Climate change adaptation & $\begin{array}{l}\text { "The political, economic and social impacts (...) from changes taking place } \\
\text { elsewhere in the world" (Foresight 2011; Gledhill et al. 2013) }\end{array}$ \\
\hline $\begin{array}{l}\text { Interregional } \\
\text { linkage }\end{array}$ & Ecology & $\begin{array}{l}\text { "The sustainability of any specified region increasingly depends directly and } \\
\text { indirectly on the ecological sustainability of other regions" (Kissinger and } \\
\text { Rees 2010) }\end{array}$ \\
\hline Secondary effect & Climate change adaptation & $\begin{array}{l}\text { "Effects resulting from international climate change impacts" (Hunt et al. } \\
\text { 2009) }\end{array}$ \\
\hline $\begin{array}{l}\text { Societal } \\
\text { teleconnection }\end{array}$ & Climate change adaptation & $\begin{array}{l}\text { A link between "activities, trends, and disruptions across large distances, } \\
\text { such that locations spatially separated from the locus of an event can } \\
\text { experience a variety of impacts from it nevertheless" (Moser and Hart 2015) }\end{array}$ \\
\hline Spillover effect & Economics & $\begin{array}{l}\text { "Impacts of climate change affecting welfare in regions different from the } \\
\text { one where the shock has occurred" (Schenker 2013) }\end{array}$ \\
\hline Systemic risk & Risk assessment & $\begin{array}{l}\text { "Risks arising from interactions between changes in the physical climate and } \\
\text { human systems" (King et al. 2015) }\end{array}$ \\
\hline Teleconnection & $\begin{array}{l}\text { Atmospheric sciences, } \\
\text { social ecology, land-use } \\
\text { change }\end{array}$ & $\begin{array}{l}\text { Dynamic process that links distant and sometimes multiple places (see e.g. } \\
\text { Adger et al. 2009; Bren d'Amour et al. 2016; Challies et al. 2014; Eakin et } \\
\text { al. 2009; Mulligan 2015; Seto et al. 2012; Yu et al. 2013). }\end{array}$ \\
\hline Telecoupling & $\begin{array}{l}\text { Land-use change, } \\
\text { environmental politics }\end{array}$ & $\begin{array}{l}\text { "Socioeconomic and environmental interactions among coupled human and } \\
\text { natural systems over distances" (Liu et al. 2013) (see also Eakin et al. 2014; } \\
\text { Lenschow et al. 2016) }\end{array}$ \\
\hline $\begin{array}{l}\text { Transboundary } \\
\text { impact }\end{array}$ & $\begin{array}{l}\text { Water management, air } \\
\text { pollution }\end{array}$ & $\begin{array}{l}\text { Impact traversing national borders (see e.g. Beck and Bernauer 2011; } \\
\text { Goulden et al. 2009; Hollaway et al. 2012; Timmerman et al. 2011; } \\
\text { Tzanidakis et al. 2013) }\end{array}$ \\
\hline $\begin{array}{l}\text { Transnational } \\
\text { impact }\end{array}$ & Climate change adaptation & $\begin{array}{l}\text { "Impacts [that] reach across borders, affecting one country (...) as a result of } \\
\text { climate change or climate-induced extreme events in another country" } \\
\text { (Benzie et al. 2016) }\end{array}$ \\
\hline
\end{tabular}


The term cross-border impact was chosen for this study as it can be applied to a geographical area of choice, such as multi-national entities (e.g. EU), regions within a country (e.g. individual states of a country), or to natural biomes (e.g. tropical, temperate or polar regions). It offers enough flexibility to be used in different contexts, while at the same time accentuating the idea of impacts crossing some kind of border. The term is also gathering some momentum in research (Benzie et al. 2017) and policy circles (EEA 2017).

There are currently no frameworks or methodologies for studying cross-border impacts, but there are attempts to conceptualise the issue. Most of the studies concerning cross-border impacts focus on identifying how the impacts are transmitted from one physical location to the next, rather than assessing the effects themselves. For instance, Liu et al. (2013) and Moser \& Hart (2015) presented conceptual frameworks to clarify and advance the understanding of crossborder impacts. The frameworks are similar and compose of a relationship between two places, flows of substances between them, and agents and institutions either facilitating or hindering the process. These frameworks help explain the complex nature of cross-border systems but are not applicable for assessing specific impacts. Winkler et al. (2010) proposed a quantitative hybrid modelling approach to facilitate the conduction of comprehensive industry-wide vulnerability assessments of market systems with multiple spatially separated production regions and long-term investments, in the face of climate change. This is useful but too complicated for more general climate vulnerability assessments. Benzie et al. (2016) developed an index for assessing the level of exposure of different countries to crossborder impacts. The study raises awareness of the issue and successfully highlights the importance of cross-border impacts, but is not directly transferrable to sector-specific assessments. Gotangco et al. (2017) used a supply chain approach to assess cross-border vulnerabilities to climatic hazards facing the Metro Manila area in the Philippines. The study focused on a variety of vulnerabilities, whereas this paper is concerned with the energy sector specifically. In terms of methodology, supply chain approaches are increasingly used within the private sector to highlight risks and improve the resilience of important international supply chains to climate change impacts (BSR 2016; Norton et al. 2015), although no climate change risk assessments specifically focusing on energy supply chains could be found.

\subsection{Vulnerability of the energy sector to climate change}

Within the vulnerability literature, there are studies that address the vulnerability of the energy sector in general (Schaeffer et al. 2012), specific technologies or infrastructures (e.g. Brown et al., 2014; van Vliet et al., 2016), or individual energy sources or carriers (e.g. Fant et al., 2016; Tarroja et al., 2016). It is important to bear in mind that vulnerability within the energy sector is a complex issue and can materialise very differently, depending on the characteristics of the dominant energy sources and carriers. For instance, electricity markets differ substantially from oil and gas markets in several ways. While oil and gas can be stored and transported over long distances, electricity is characterised by non-storability (Larsen 
et al. 2017), which means effective real-time balancing of supply and demand is required (Greenleaf et al. 2009). Oil and gas are traded in global markets, while the price of electricity is locally dependent. Furthermore, the infrastructure and regulation mechanisms are very different (Larsen et al. 2017).

In general, both extraction of different energy sources and production of different energy carriers are vulnerable to extreme weather events, increased temperatures or reduced availability of water, which may impair energy infrastructure or electricity generation (Schaeffer et al. 2012). Transportation of energy products is vulnerable to extreme weather, such as flooding, heavy rainfall, landslides (Ekmann 2013) or permafrost thawing in the Arctic (Nelson et al. 2002; Stephenson et al. 2011). Projections indicate a change in demand for energy with an increasing need for cooling and a decreasing need for heating in a warmer world (Arent et al. 2014; Mideksa and Kallbekken 2010; Wilbanks et al. 2014).

Severe local disruptions to the extraction, production or transportation of energy products may have cross-border impacts on distant countries and regions in the form of e.g. supply disruptions, price volatility or changes to energy policies (Mohaddes and Pesaran 2016). International and regional climate negotiations and energy roadmaps to curb the emissions of GHGs and decrease the share of fossil fuels in the energy mix, can in turn result in energy price volatility (Bauer et al. 2015; Umbach 2010), or changes in demand and consumption patterns (Greenleaf et al. 2009). Another potential crossborder impact (affecting energy exporters) is a change in comparative advantage between energy producers, brought about by the need to reduce emissions from the supply sector. This may be realised by developing and implementing emissionreducing technologies such as carbon capture and storage (CCS), thus gaining increased attractiveness as a supplier. Macroeconomic and other global or regional impacts of climate change on the energy sector are not well understood but could be very important (Arent et al. 2014), and are therefore imperative for a complete assessment of cross-border impacts on the energy sector, due to the globalised or regional nature of most energy markets. For small, open and international economies, such as the Nordic countries, cross-border impacts may be equally or even more important than direct impacts of climate change (Benzie et al. 2016).

\section{Framework and methods}

We present a supply-chain framework that classifies cross-border impacts of climate change on the energy sector into three categories: I) Impacts on security of supply, due to disruptions caused by direct impacts of climate change on extraction, production and transportation of energy in supplier countries, II) impacts affecting export of energy products, due to direct climate change impacts on transportation infrastructure, import terminals or refineries in consumer countries, increased or decreased demand for energy in consumer countries, or changes in comparative advantage between suppliers, and III) impacts stemming from the global context, meaning changes in global energy markets and implications from 
international climate and energy policies, which may result in price volatility or changing demand or consumption patterns. The framework facilitates the identification of nodes of vulnerability to cross-border impacts of climate change, both for imports and for exports. Impacts stemming from the global context are overarching and relevant for both importers and exporters (Figure 1).

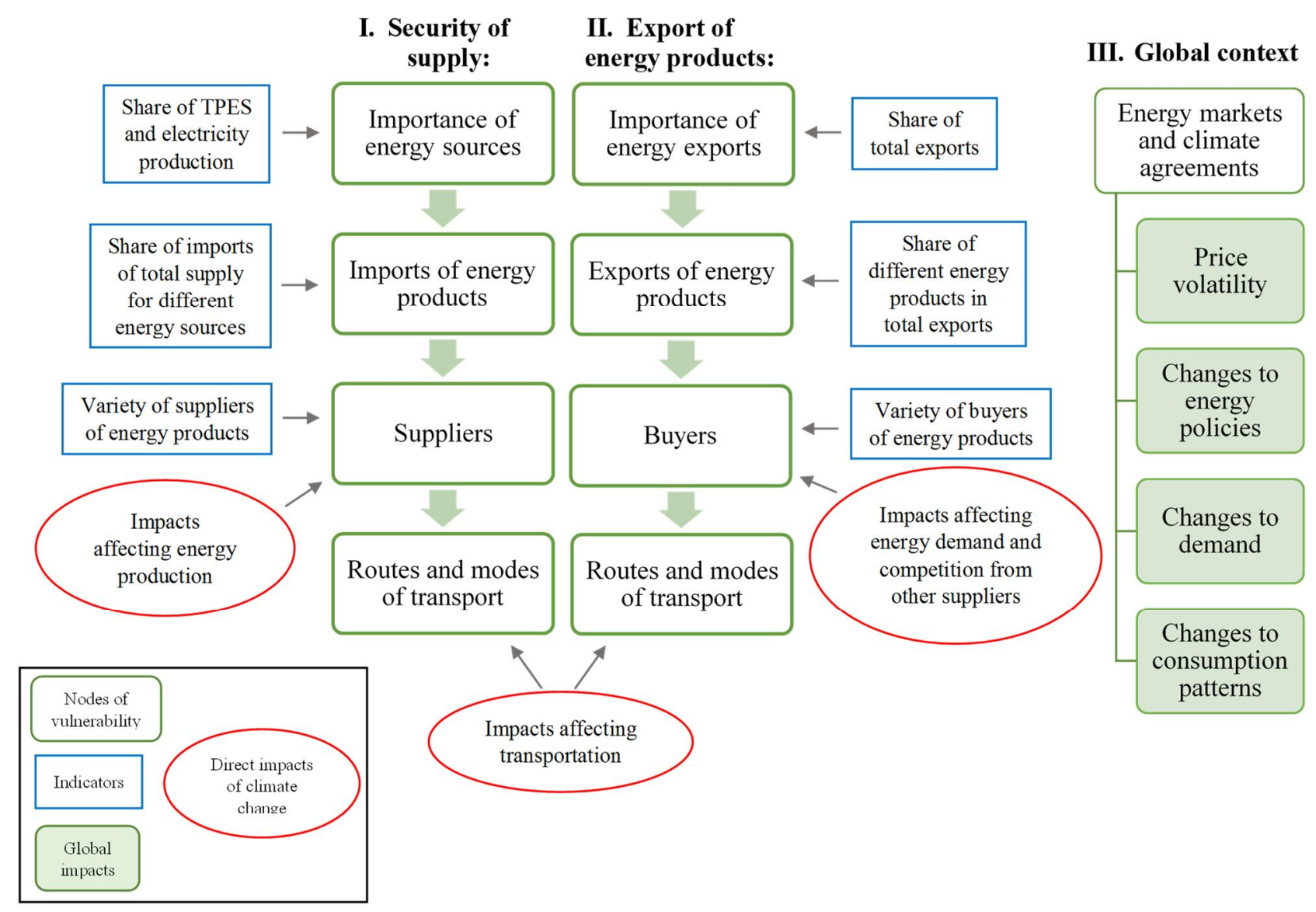

Figure 1. Framework for facilitating the identification of vulnerabilities to cross-border impacts in the energy sector.

The framework is implemented in a step-wise manner using the following economic indicators: 1) the shares of different energy sources in total primary energy supply (TPES) and domestic electricity generation, as well as the share of energy exports of total exports, 2) the shares of imported energy of total supply for each energy product and/or the specific energy products being exported, and 3) most important trade partners for imports and exports. The shares of energy sources in TPES and electricity generation reveal which sources are most important for a country's energy supply, while the share of energy exports of total exports shows how significant the export of energy products is for the economy of a country. The share of imports in total energy supply highlights how dependent a country is on imported energy versus domestically produced energy, while pinpointing the specific energy products being exported reveals the degree of versatility in energy exports. Finally, knowing the individual shares of different trade partners in both imports and exports of energy, indicates 
how dependent a country is on specific suppliers and buyers. Only energy products deemed important in previous steps need to be retained in subsequent steps of the analysis. This data serves as indicators for how internationally connected the national energy sector is, which gives a hint of its potential vulnerability to cross-border impacts. Once internationally traded energy products of national importance have been identified, the supply chain nodes, i.e. routes and modes of transport, storage, processing etc., for imports and/or exports of these products need to be identified. The framework points out potential direct impacts of climate change, which may affect the supply chain or the energy sector.

To operationalise the framework, economic indicators (as described previously) for all five Nordic countries, i.e. Finland, Sweden, Norway, Denmark and Iceland, was compiled. The main source of data for identifying shares in TPES, electricity production, exports and imports was the International Energy Agency (IEA) country statistics (IEA 2017), while the identification of trade partners relied on the United Nations (UN) Comtrade database (UN 2016). The data can be found in the supplementary material to this paper. The focus is on the current Nordic energy sectors, as economic indicators are easily obtainable, and major changes to the energy sectors are not projected to be realised until later this century (IEA 2016), while effects of climate change may be felt already earlier. Consequently, examining the impacts of a 'businessas-usual scenario is relevant. Furthermore, three examples were chosen to illustrate the usability of the framework. The examples are from Finland, Norway and Denmark, and reflect the categorisation of cross-border impacts into impacts affecting security of supply, the export market and the global context, respectively.

Compiling data from all five Nordic countries enabled a comparison between the countries, identifying which of the countries' energy sectors are potentially most vulnerable to cross-border impacts, regarding imports and exports separately. A comparison is useful, since all five countries have similar political, economic and social structures, but differ to various degrees in their energy profiles, thus highlighting the exposure of different energy systems to crossborder impacts and the importance of sound decision making in energy and climate policies. To facilitate the comparison of the countries, the Energy Import and Export (EIE) index was developed. The import-ranking is based on the importance of different energy sources, import-dependency, and reliance on just a few suppliers. It was developed by summing for every country the shares of TPES, electricity production, imports of total supply, and imports from the most important supplier for oil, oil products, coal, natural gas, nuclear fuel (only Finland and Sweden), biofuel and electricity imports, individually, where applicable. The sums were then divided by 4 (3 for electricity imports because electricity production was not applicable) to obtain a number between 1 and 100. The numbers were further summed together and divided by 6 (7 for Finland and Sweden) to again obtain a number between 1 and 100. This is a simple way of creating an index in which all factors weigh equally. The export-ranking takes into account the importance of energy exports for the national economy, variety of energy products exported, and the reliance on just a few trade partners. It was developed in a similar 
way as the import index, although only two variables were used, namely the share of each energy product in total energy exports, and the share of the most important buyer. The sums were divided by 2, summed again, and divided by 6 for each country. Lastly, the share of energy exports in total exports was added. The index does not account for the vulnerability of trade partners to climate change impacts. The data used in the index can be found in the supplementary material.

Finally, relevant documents and governmental reports of the Nordic countries were reviewed, to assess to what extent cross-border impacts are addressed within the countries' energy and climate policies.

\section{Results}

\subsection{The framework}

In the following, the results from the gathering of economic indicators are presented, followed by three illustrative examples of vulnerabilities to cross-border impacts within the energy sectors of the Nordic countries. Tables of the economic indicators are found in the supplementary material.

\subsubsection{Importance of different energy sources and energy exports}

Hydropower and petroleum together account for $80 \%$ of TPES in Norway, and electricity production is almost completely based on hydropower. Sweden's TPES is divided between nuclear power (35\%), petroleum (24\%) and bioenergy (24\%), while electricity production is based on equal amounts of nuclear and hydro. Bioenergy and petroleum both account for around $26 \%$ of Finnish TPES, and nuclear power dominates electricity production with 35\%. Denmark uses large amounts of petroleum (37\% of TPES) as well as wind power ( $41 \%$ of electricity production), but coal and bioenergy are also used in significant amounts. Iceland takes advantage of large domestic resources of geothermal energy (accounting for $70 \%$ of TPES) and hydropower, which dominates electricity production with 70\% (IEA 2017).

Norway is highly dependent on export revenues from the energy sector, accounting for approximately $50 \%$ of all exports from the country (Nærings- og fiskeridepartementet 2017). In Finland, Sweden and Denmark, energy exports account for around $10 \%$ of total exports, while the same number for Iceland is $2 \%$ (IEA 2017).

\subsubsection{Different energy products in imports and exports}

Norway is one of the leading exporters of crude oil and natural gas in the world, accounting for around $50 \%$ and $40 \%$ of energy exports from the country, respectively. Conversely, imports of energy products to Norway is less important, and although more than $90 \%$ of coal is imported, its low share in TPES and electricity generation makes it irrelevant for further analysis. Sweden and Finland have quite similar energy profiles, being highly dependent on imports of both fossil fuels and uranium due to negligible (or unprofitable) domestic reserves of these energy sources. They are also important 
exporters of refined oil products. Although bioenergy is used in substantial amounts in both countries, it is mostly a domestic resource and therefore not relevant for further analysis. Denmark is an interesting case, both importing and exporting substantial amounts of fossil fuels (IEA 2017). Denmark is usually a net exporter of natural gas, crude oil, gasoline and residual fuel oil, and a net importer of middle distillates as well as coal. As the Danish oil and gas reserves are in decline, Denmark will probably become more dependent on imports in the future (IEA 2014). Additionally, more than $30 \%$ of electricity and around $27 \%$ of biofuels used in Denmark are imported. Iceland is virtually self-sufficient in energy, due to its reliance on domestic resources of geothermal energy and hydropower. However, the Icelandic transport sector depends on imported oil products, due to a lack of domestic fossil fuel resources or oil refineries (IEA 2017).

\subsubsection{Important trade partners}

The most important buyers of Norwegian crude oil and natural gas are the UK and Germany. The Netherlands also buy substantial amounts of crude oil, while France is an important buyer of natural gas. Sweden relies heavily on Russia for the supply of crude oil. Sweden exports oil products mainly to the UK and buys them mainly from Finland. Canada and Australia are the major suppliers of uranium to Sweden. Finland is almost exclusively dependent on Russia for imports of fossil fuels, with Russia accounting for $94 \%$ of gas, $83 \%$ of crude oil, $50 \%$ of coal, and almost $40 \%$ of oil products imported to Finland. Canada, Australia and Russia provide the bulk of uranium to Finnish nuclear power plants. Additionally, Finland exports significant amounts of oil products mainly to Sweden, the Netherlands and the USA. Denmark has the most diversified energy trade profile, due to its location between the Nordics and the European mainland. Norway supplies most of the crude oil imported to Denmark, along with substantial amounts of oil products, natural gas and electricity. Germany is an important supplier of natural gas, coal and electricity. Other important suppliers are the UK, Sweden, Nigeria, Qatar and Australia. Important buyers of Danish energy products are the UK, Sweden, the Netherlands, Norway and Germany. Iceland is dependent on imports of oil products, with Norway the most important supplier (UN 2016).

\subsubsection{Routes and modes of transport}

For the last step of identifying routes and modes of transport, as well as highlighting vulnerabilities of the energy sector to cross-border impacts, three examples were chosen: The import supply chain for crude oil and natural gas to Finland, the export supply chain for crude oil and natural gas from Norway, and global impacts on the Danish electricity market. These examples were deemed the most illustrative of the three categories described previously. A literature review was conducted to obtain information on the supply chains and projected climate change impacts that may affect them. The examples are short illustrations, and would benefit from more extensive analyses, which is out of scope for this paper. It is important to note that all Nordic countries could be affected by all categories of cross-border impacts and especially 
impacts stemming from the global context are overarching and complex. A short summary of the most important crossborder impacts for the Nordics are found in Table 2.

Table 2. Summary of the most important cross-border impacts on the energy sectors of the Nordic countries.

\begin{tabular}{|c|c|}
\hline & Cross-border impacts \\
\hline Norway & $\begin{array}{l}\text { - Export of fossil fuel is affected by changing demand in importing countries } \\
\text { - Impacts on pipelines and other energy infrastructure outside Norwegian territories could disrupt exports } \\
\text { - Changes in competition from other suppliers affect exports } \\
\text { - Changes in the global price for oil and gas affects export revenues } \\
\text { - International climate negotiations affect national energy policies }\end{array}$ \\
\hline Sweden & $\begin{array}{l}\text { - Impacts on Arctic oil fields in Russia and offshore platforms in the Norwegian Sea, as well as on tankers, can cause } \\
\text { disruptions to supply of petroleum and natural gas } \\
\text { - Changing demand for oil products affects exports } \\
\text { - Impacts, such as flooding, on uranium mines may affect supply } \\
\text { - The complex transportation chain for nuclear fuel makes it inherently vulnerable to climate change } \\
\text { - Changes in the global price of fossil fuels affect both imports and exports } \\
\text { - Changes in competition from other suppliers affect exports of oil products } \\
\text { - International climate negotiations affect national energy policies }\end{array}$ \\
\hline Finland & $\begin{array}{l}\text { - Impacts on oil and gas fields in Russia can cause disruptions to supply of both petroleum and natural gas } \\
\text { - Damage to the gas pipeline network in Russia could disrupt supply } \\
\text { - Changing demand for oil products affects exports } \\
\text { - Impacts, such as flooding, on uranium mines may affect supply } \\
\text { - The complex transportation chain for nuclear fuel makes it inherently vulnerable to climate change } \\
\text { - Changes in the global price of fossil fuels affect both imports and exports } \\
\text { - Changes in competition from other suppliers affect exports of oil products } \\
\text { - International climate negotiations affect national energy policies }\end{array}$ \\
\hline Denmark & $\begin{array}{l}\text { - Impacts on offshore oil platforms in the Norwegian Sea and on tankers can cause disruption to supply } \\
\text { - Damage to the European gas pipeline network can disrupt supply } \\
\text { - Damage to the European electricity transmission network can disrupt supply } \\
\text { - Impacts such as flooding, can disrupt the supply of coal } \\
\text { - Export of fossil fuel is affected by changing demand in importing countries } \\
\text { - Increasing demand for gas in Europe can restrain the amount of gas available to Denmark } \\
\text { - Changes in the global price of fossil fuels affect both imports and exports } \\
\text { - Changes in competition from other suppliers affect exports } \\
\text { - International climate negotiations affect national energy policies }\end{array}$ \\
\hline Iceland & $\begin{array}{l}\text { - Impacts on offshore oil platforms in the Norwegian- and North Seas and on tankers can cause disruption to supply } \\
\text { - Changes in the global price of fossil fuels affect imports } \\
\text { - International climate negotiations affect national energy policies }\end{array}$ \\
\hline
\end{tabular}

\subsubsection{Example I: Imports of crude oil and natural gas to Finland}

Finland is dependent on Russia for imports of oil and natural gas, accounting for almost all of domestic supply (UN 2016).

Crude oil is transported by tankers over the Baltic Sea, while natural gas is transported through a twin pipeline entering Finland in the southeast (IEA 2013). The dependency on a single supplier, and subsequently a single supply chain, increases the vulnerability to cross-border impacts, as any disruptions to the supply chain would affect the entire supply. For instance, Rodríguez-Gómez et al. (2016) found the vulnerability of Finland to a gas disruption in Russia, whether induced by climate change or some other factor, to be very high. 
Many of the biggest Russian oil and gas fields are located in areas with permafrost (Center for Geographic Analysis 2015), and therefore vulnerable to infrastructural damage caused by ground subsidence, landslides, and coastal erosion induced by thawing of permafrost (Cruz and Krausmann 2013; Streletskiy et al. 2014). The western Siberian pipeline network is especially vulnerable due to inadequate environmental and engineering standards coupled with vast permafrost areas (Nelson et al. 2002). Both above-ground and subsurface pipelines are vulnerable to changes in the freezing-thawing processes of permafrost, as well as soil erosion caused by heavy flooding, which may cause damage and subsequent oilleakage to the pipeline (Li et al. 2010; Streletskiy et al. 2014; Vlasova and Rakitina 2010). Stephenson et al. (2011) found that some winter road networks of Siberia could become inoperative by mid- $21^{\text {st }}$ century, implying reduced accessibility to some onshore oil and gas fields, as the marshy Arctic tundra generally is not able to support heavy transportation in summer (Harsem et al. 2011). This was confirmed by Streletskiy et al. (2014), who argued that regions of oil and gas development in western Siberia have already experienced a significant decrease in the operational length of winter roads. Additionally, strong winds impede the setting up of oil rigs and cementing of boring wells, while thunder storms are extremely dangerous for the operation of pipelines (Akentyeva 2010).

Furthermore, several gas fields are located offshore in the Kara and Barents Seas (Center for Geographic Analysis 2015) and are vulnerable to extreme weather such as heavy storms, as well as floating icebergs (Froude and Gurney 2010; Harsem et al. 2011). The reduction in Arctic sea ice in the future may open up opportunities for further exploration of oil and gas in Russian waters, as especially the Kara and Barents Seas are projected to experience a very pronounced reduction in the length of the ice season in the $21^{\text {st }}$ century (Khon et al. 2010). There are, however, numerous impediments related to this, e.g. high costs, a hostile environment, climate- and environmental concerns, political rigidity and uncertain future trends in demand and prices on the global energy market (Harsem et al. 2011; Lindholt and Glomsrød 2012; Moe 2010). Furthermore, a prolonging of the ice-free season accelerates coastal erosion, as the coast is no longer protected from waves by a thick layer of ice, which already has had negative impacts on several oil terminals on the northern Russian coast (Streletskiy et al. 2014).

\subsubsection{Example II: Exports of crude oil and natural gas from Norway}

Crude oil and natural gas are the most important energy products exported from Norway. Around $45 \%$ of the oil and $30 \%$ of the gas are destined for the UK, another $30 \%$ of the gas is shipped to Germany (UN 2016). Transportation of natural gas as well as most of the crude oil is mainly through submerged pipelines from several offshore platforms in the North Sea or mainland terminals. Some of the oil is also transported by tankers (IEA 2014), which could be affected by heavy storms, storm surges and potential rogue waves (Bitner-Gregersen et al. 2013). Direct impacts of climate change on terminals, ports, refineries or distribution networks in receiving countries, could temporarily reduce demand for oil and 
gas by reducing the amount of these products that the countries are able to receive. For instance, coastal infrastructure is vulnerable to sea-level rise, storm and tidal surges, coastal erosion and floods, while rough seas can prevent tankers from docking. The distribution network (consisting of pipelines, roads, rails and inland water ways), delivering oil and oil products to consumers, is vulnerable to e.g. flooding, erosion, high winds, thermal loading of pavements, and buckling of rails (Dawson et al. 2016).

Demand for oil and gas in the UK and Germany may change in the future. For instance, oil imports to the UK is projected to increase in the near future due to declining domestic production in the UK (DECC 2012). However, total demand for oil will likely decrease in the longer term in both the UK and Germany due to national renewable energy and climate

change targets. Additionally, as global demand for oil decreases, competition among exporters for the remaining customers will likely increase. UK oil refineries, for instance, have been experiencing increasing competition mainly from Asian refineries, which have resulted in the closing-down of some of the refineries in recent years (DECC 2012).

\subsubsection{Example III: Electricity trade in Denmark}

International trade in electricity is significant in Denmark, being the distributor between the Nordic and European electricity markets. More than $30 \%$ of electricity supply is imported, with around $40 \%$ coming from Sweden, and the rest divided between Norway and Germany. These three countries are also the main trade partners for exports of electricity, comprising around 5.5\% of energy exports from Denmark (UN 2016). The distribution and transmission of electricity is sensitive to climate change impacts affecting electricity generation (e.g. water scarcity) (Schaeffer et al. 2012) and overhead lines (e.g. high winds or forest fires) (Ward 2013). In addition, EU climate change mitigation policies, focusing on reducing GHGs and increasing the share of renewables in energy production and supply, are likely to transform the electricity market within the EU by aiming for more integration among member countries (European Commission 2011). A common regional electricity market would likely result in substantial geopolitical implications for member states, due to reshuffling of energy assets, new markets and new competitors (Ydersbond et al. 2014). As Denmark is a net importer of electricity, any changes in prices or sudden supply shortages due to extreme events in other parts of Europe could have significant consequences (Larsen et al. 2017).

As an example, Zakeri et al. (2016) examined the impacts of the German energy transition policies (Energiewende) on the Nordic electricity market and concluded that Denmark would be the country most affected. The Energiewende was projected to induce an initial average electricity price increase of around $4 \%$ in Denmark in the short run, but the increase would diminish slightly up until 2030. It was also projected to result in congestion of the Danish transmission lines more often than today, due to increasing trade back and forth between the German and Nordic markets. Grid congestions can cause power outages and increased prices for consumers, but also increase the revenues to grid operators through higher 
congestion rents. Further, the flexibility of the Danish energy system was projected to be constrained by $20 \%$ due to higher wind curtailment, which refers to electricity from wind that cannot be consumed, stored, or exported because of market saturation or transmission congestions. Lastly, higher demand for electricity generation in Denmark, induced by the Energiewende, could lead to increased GHG emissions (Zakeri et al. 2016).

\subsection{The Energy Import and Export (EIE) index}

Combining the economic indicators into the EIE index, illustrates how internationally connected the Nordic energy sectors are in comparison to each other and gives an indication of which countries are potentially most vulnerable to cross-border impacts of climate change. Finland scores highest on the import ranking, due to complete reliance on imports of fossil fuels (with only one major supplier) and uranium. Norway has the highest score on the export ranking, because of the significance of energy exports for the country. Iceland's energy sector is based on domestic resources of hydro and geothermal power, and as such received low scores for both imports and exports. Even though Sweden and Denmark are highly involved in international energy trade, they are not as dependent on a single supplier as Finland nor is the share of energy exports as high as in Norway (Figure 2).

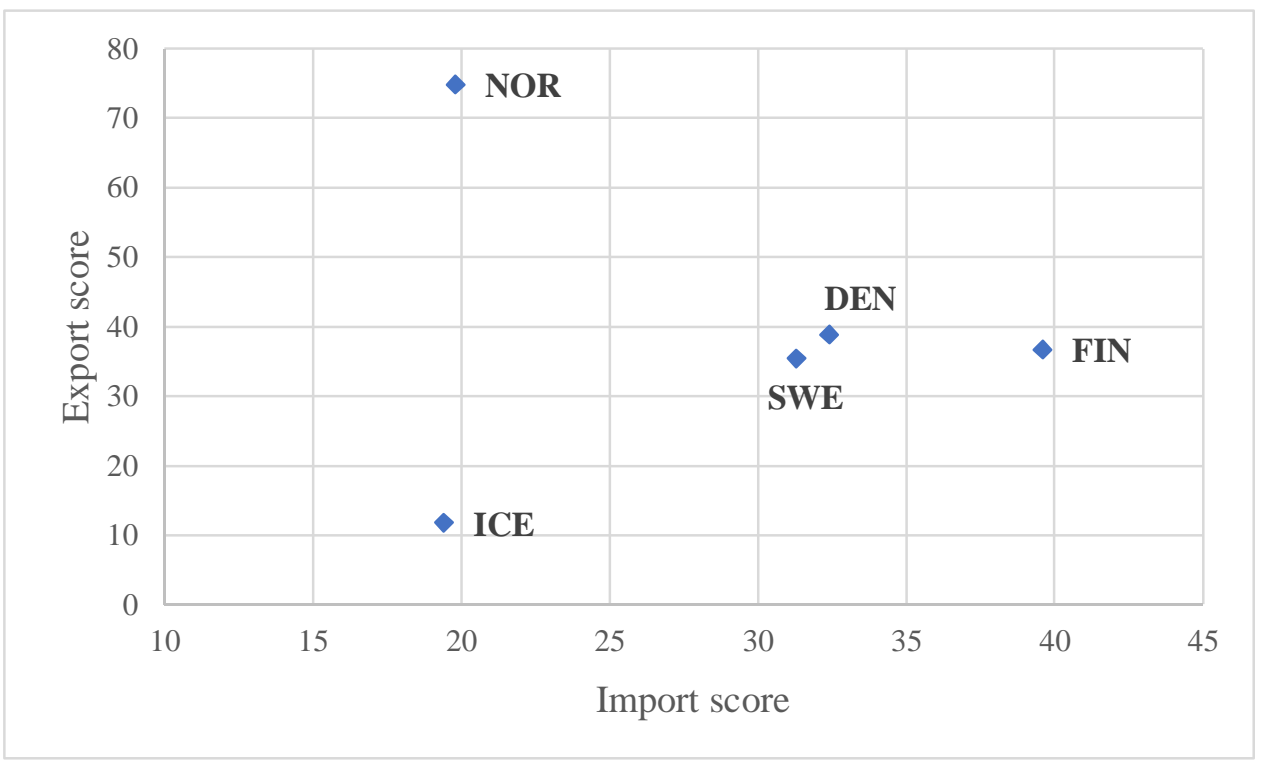

Figure 2. The EIE index shows how internationally connected the energy sectors of the Nordic countries are in relation to each other, and gives an indication of the level of vulnerability to cross-border impacts among the countries.

\subsection{Cross-border impacts in national climate and energy strategies}

Hitherto, national climate strategies and assessments have rarely comprehensively accounted for cross-border impacts. The importance of cross-border impacts for national climate risk assessments was first highlighted in 2011 within a UK government-funded project. In the report, risks to foreign policy and security, finance and business, infrastructure, 
availability of resources and commodities, and health were emphasised and briefly assessed (Foresight 2011). Gledhill et al. (2013) later compared these cross-border impacts to projected direct impacts in the UK to assess their significance. Additionally, a whole chapter of the UK Climate Change Risk Assessment 2017 Evidence Report is devoted to crossborder impacts concerning food systems, migration and displacement risks, as well as risks associated with geopolitical instability (Challinor et al. 2016). Some other national adaptation strategies, such as Germany's (The Federal Government of Germany 2008) acknowledge the importance that cross-border impacts may have, especially on development cooperation and international trade, but does not try to assess these risks any further. Liverman (2016) identified crossborder impacts as one of the research priorities in need of strengthening in the Third US National Climate Assessment.

In the Nordics, energy issues are discussed within the national strategies from a national perspective: there is an assumption in all Nordic countries that energy demand is likely to decrease during the winter due to higher winter temperatures, while there might be an increase in demand during the summer months due to increased need for cooling. From the supply side, the national strategies mainly focus on the role of extreme events affecting domestic production of energy. There is no explicit focus on impacts on transmission or trade. A lack of information and expertise, as well as policy actions to support adaptation planning dealing with cross-border impacts, is evident in all five Nordic countries. This may result in significant risks being overlooked and neglected, seriously undermining the effectiveness of national adaptation policy. Nevertheless, cross-border impacts are increasingly being recognised and the need for more research in this field has been emphasised in several governmental reports (Table 3).

Table 3. Summary of the level of incorporation of cross-border impacts within national climate and energy strategies and other official documents of the Nordic countries.

\begin{tabular}{|c|c|}
\hline & Incorporation of cross-border impacts \\
\hline Norway & $\begin{array}{l}\text { The governmental report "Adapting to a changing climate" (Government of Norway 2010) identifies cross-border risks } \\
\text { affecting global food prices, international development aid, and cooperation in the Arctic. The national energy } \\
\text { strategies from } 2012 \text { and } 2016 \text { (OED 2012, 2016) acknowledge that international climate negotiations will affect the } \\
\text { global energy market with implications for e.g. prices and energy demand in Europe, with potentials for expanding the } \\
\text { European electricity grid. It is highlighted that changes to the electricity production of other Nordic countries could } \\
\text { impact the availability of electricity on the Nord Pool market. }\end{array}$ \\
\hline Sweden & $\begin{array}{l}\text { The Swedish Meteorological and Hydrological Institute, in its governmental report "Basis for the checkpoint-2015 for } \\
\text { adapting to a changing climate" (Andersson et al. 2015), highlights the need for more research on cross-border impacts } \\
\text { as part of their recommendations on how to upgrade and improve national work on climate change adaptation. The } \\
\text { energy and transport sectors were brought forward as two of the sectors in need of vulnerability assessments. }\end{array}$ \\
\hline Finland & $\begin{array}{l}\text { The National Energy and Climate Strategy (Ministry of Employment and the Economy 2013) recognises the potential } \\
\text { importance of cross-border impacts of climate change, while the National Climate Change Adaptation Plan (Ministry } \\
\text { of Agriculture and Forestry 2014) proposes the incorporation of cross-border impacts in national adaptation planning } \\
\text { and highlights the need for more research on these impacts. Implications for the energy or transport sectors were not } \\
\text { mentioned. }\end{array}$ \\
\hline Denmark & $\begin{array}{l}\text { The Task Force for Climate Change Adaptation (2012) recognises the effect on electricity prices in Denmark that } \\
\text { climate change impacts in Norway and Sweden may have. Overall, the need for adaptation in the energy sector is seen } \\
\text { as modest. }\end{array}$ \\
\hline
\end{tabular}


According to the CoastAdapt report "Adapting to climate change in Iceland" (CoastAdapt 2012), there is no national Iceland strategy for adapting to climate change, as the need for governmental guidelines for adaptation is considered unnecessary. The report argues that Iceland will be affected by climate change impacts in other countries due to the global Icelandic economy.

\section{Discussion and conclusions}

This paper advances the research on cross-border impacts of climate change and brings forward the energy sector as particularly vulnerable, illustrated by three examples from the Nordic countries. Our analysis shows that all the Nordic countries are vulnerable to various degrees to potential cross-border impacts of climate change, due to the Nordic energy systems being highly globalised and interconnected. In particular, Finland and Sweden are mostly vulnerable to crossborder impacts affecting supply of fossil fuel and uranium, resulting from direct climate change impacts on extraction, production and transportation. Denmark and Norway, being important exporters of oil and natural gas, are vulnerable to changes in demand for these products in consumer countries. Denmark also imports substantial amounts of electricity, which will be particularly affected by regional climate agreements and the implementation of a common EU electricity market. Iceland could be considered the least vulnerable to cross-border impacts because of relatively little trade in energy products, and thus less exposed to cross-border impacts on supply chains. International climate negotiations may have implications for the global energy market, with cross-border impacts, such as price volatility, on all five countries. Despite the potential significance that cross-border impacts of climate change may have on the Nordic countries, these are not considered in national climate assessments and energy strategies.

The framework allows for the identification of vulnerabilities to cross-border impacts within the energy sector of a country. While the application of the framework on an empirical case allows for the initial identification of vulnerabilities, literature reviews, downscaled climate scenarios combined with spatially explicit risk assessments, and interviews with experts can further be used to identify location-specific impacts and assess their importance. Thus, further analysis requires methodological development to address the specific vulnerabilities within the supply chains of multiple energy products. This can include more place-based vulnerability assessments with regional climate scenarios to focus on energy production, as well as methods to assess impacts of climate change on trade and transportation along the supply chain. By properly including cross-border impacts in climate assessments, it is possible to obtain a more complete picture of risks involved. This is true, not only in the Nordics, but in all countries of the world, especially developed countries, where a large part of commodities, food and energy is imported.

The energy sectors of the Nordic countries, along with many other developed countries, are in an era of transition away from fossil fuels towards more renewable and low-carbon energy, brought about by the global context of international 
climate negotiations and GHG mitigation pledges. As the energy system changes, so does the international connections of a country, which in turn entails new cross-border impacts of climate change. No studies have as yet assessed crossborder impacts on a low-carbon energy system, even though international trade in energy is likely to remain very important in a low-carbon world (Scholten and Bosman 2016). A similar framework and supply chain approach as used in this paper could be used for assessing a low-carbon energy system, and this study could provide a 'business-as-usual' scenario for comparison.

\section{References}

Adger WN, Eakin H, Winkels A (2009) Nested and teleconnected vulnerabilities to environmental change. Front Ecol Environ 7:150-157 . doi: 10.1890/070148

Akentyeva EM (2010) Requirements of oil and gas operations for climate data, information, products and services in the high latitudes. In: Troccoli A (ed) Management of Weather and Climate Risk in the Energy Industry. Springer, Dordrecht, pp 165-172

Andersson L, Bohman A, van Well L, et al (2015) Underlag till kontrollstation 2015 för anpassning till ett förändrat klimat. Swedish Meteorological and Hydrological Institute, Norrköping

Arent DJ, Tol RSJ, Faust E, et al (2014) Key economic sectors and services. In: Field CB, Barros VR, Dokken DJ, et al. (eds) Climate Change 2014: Impacts, Adaptation, and Vulnerability. Part A: Global and Sectoral Aspects. Contribution of Working Group II to the Fifth Assessment Report of the Intergovernmental Panel on Climate Change. Cambridge University Press, Cambridge and New York, pp 664-672

Arnell NW, Brown S, Gosling SN, et al (2016) The impacts of climate change across the globe: A multi-sectoral assessment. Clim Change 134:457-474 . doi: 10.1007/s10584-014-1281-2

Bauer N, Bosetti V, Hamdi-Cherif M, et al (2015) CO2 emission mitigation and fossil fuel markets: Dynamic and international aspects of climate policies. Technol Forecast Soc Change 90:243-256 . doi: 10.1016/j.techfore.2013.09.009

Beck L, Bernauer T (2011) How will combined changes in water demand and climate affect water availability in the Zambezi river basin? Glob Environ Chang 21:1061-1072 . doi: 10.1016/j.gloenvcha.2011.04.001

Benzie M, Carter T, Groundstroem F, et al (2017) Implications for the EU of cross-border climate change impacts, EU FP7 IMPRESSIONS Project Deliverable D3A.2. European Commission, Stockholm and Helsinki

Benzie M, Hedlund J, Carlsen H (2016) Introducing the transnational climate impacts index: Indicators of country-level exposure - methodology report. Stockholm Environment Institute, Stockholm

Benzie M, Wallgren O, Davis M (2013) Adaptation without borders? How understanding indirect impacts could change countries' approach to climate risks. Stockholm Environment Institute, Stockholm

Bitner-Gregersen EM, Eide LI, Hørte T, Skjong R (2013) Ship and Offshore Structure Design in Climate Change Perspective. Springer-Verlag, Berlin and Heidelberg

Bradley BA, Estes LD, Hole DG, et al (2012) Predicting how adaptation to climate change could affect ecological conservation: Secondary impacts of shifting agricultural suitability. Divers Distrib 18:425-437 . doi: 10.1111/j.1472-4642.2011.00875.x

Bren d'Amour C, Wenz L, Kalkuhl M, et al (2016) Teleconnected food supply shocks. Environ Res Lett 11:35007 . doi: 10.1088/1748-9326/11/3/035007

Brown S, Hanson S, Nicholls RJ (2014) Implications of sea-level rise and extreme events around Europe: A review of coastal energy infrastructure. Clim Change 122:81-95 . doi: 10.1007/s10584-013-0996-9

Bruckner T, Bashmakov IA, Mulugetta Y, et al (2014) Energy systems. In: Edenhofer O, Pichs-Madruga R, Sokona Y, et al. (eds) Climate Change 2014: Mitigation of Climate Change. Contribution of Working Group III to the Fifth Assessment Report of the Intergovernmental Panel on Climate Change. Cambridge University Press, Cambridge and New York, pp 511-598 
BSR (2016) From Agreement to Action: Mobilizing suppliers toward a climate resilient world. Business for Social Responsibility, New York

Center for Geographic Analysis (2015) Oil map of Russia. In: WorldMap. http://worldmap.harvard.edu/maps/6176. Accessed 11 Oct 2016

Challies E, Newig J, Lenschow A (2014) What role for social-ecological systems research in governing global teleconnections? Glob Environ Chang 27:32-40 . doi: 10.1016/j.gloenvcha.2014.04.015

Challinor A, Adger WN, Di Mauro M, et al (2016) International dimensions. In: UK Climate Change Risk Assessment Evidence Report. Report prepared for the Adaptation Sub-Committee of the Committee on Climate Change, London

CoastAdapt (2012) Adapting to Climate Change in Iceland. Institute for Sustainability Studies, University of Iceland, Reykjavik

Cruz AM, Krausmann E (2013) Vulnerability of the oil and gas sector to climate change and extreme weather events. Clim Change 121:41-53 . doi: 10.1007/s10584-013-0891-4

Dawson RRJ, Thompson D, Johns D, et al (2016) Infrastructure. In: UK Climate Change Risk Assessment Evidence Report. Report prepared for the Adaptation Sub-Committee of the Committee on Climate Change, London

DECC (2012) Energy Security Strategy. UK Department of Energy and Climate Change, London

Dzebo A, Stripple J (2015) Transnational adaptation governance: An emerging fourth era of adaptation. Glob Environ Chang 35:423-435 . doi: 10.1016/j.gloenvcha.2015.10.006

Eakin H, Defries R, Kerr S, et al (2014) Significance of telecoupling for exploration of land-use change. In: Seto KC, Reenberg A (eds) Rethinking Global Land Use in an Urban Era. MIT Press, Cambridge, MA, pp 141-162

Eakin H, Winkels A, Sendzimir J (2009) Nested vulnerability: exploring cross-scale linkages and vulnerability teleconnections in Mexican and Vietnamese coffee systems. Environ Sci Policy 12:398-412 . doi: 10.1016/j.envsci.2008.09.003

Ebinger J, Vergara W (2011) Climate Impacts on Energy Systems: Key issues for energy sector adaptation. The World Bank, Washington D.C.

EEA (2017) Climate change, impacts and vulnerability in Europe 2016: An indicator-based report. European Environment Agency, Copenhagen

Ekmann J (2013) Climate impacts on coal, from resource assessments through to environmental remediation. Clim Change 121:27-39 . doi: 10.1007/s10584-013-0952-8

European Commission (2011) Energy Roadmap 2050. European Commission, Brussels

Fant C, Adam Schlosser C, Strzepek K (2016) The impact of climate change on wind and solar resources in southern Africa. Appl Energy 161:556-564 . doi: 10.1016/j.apenergy.2015.03.042

Foresight (2011) International dimensions of climate change. The Government Office for Science, London

Froude LSR, Gurney RJ (2010) Storm prediction research and its application to the oil/gas industry. In: Troccoli A (ed) Management of Weather and Climate Risk in the Energy Industry. Springer, Dordrecht, pp 241-252

Galaz V, Galafassi D, Tallberg J, et al (2014) Connected risks, connected solutions. Stockholm Resilience Centre, Stockholm University, and the Global Challenges Foundation, Stockholm

Gledhill R, Hamza-Goodacre D, Low LP, Graham H (2013) International threats and opportunities of climate change for the UK. PriceWaterhouseCoopers, London

Goldthau A (2011) The public policy dimension of energy security. In: Sovacool BK (ed) The Routledge Handbook of Energy Security. Routledge, London and New York, pp 129-145

Gotangco CK, Favis AM, Guzman AL, et al (2017) A supply chain framework for characterizing indirect vulnerability. Int J Clim Chang Strateg Manag 9:184-206 . doi: 10.1108/17568690910955603

Goulden M, Conway D, Persechino A (2009) Adaptation to climate change in international river basins in Africa: a review. Hydrol Sci J 54:805-828 . doi: 10.1623/hysj.54.5.805

Government of Norway (2010) Adapting to a changing climate. Ministry of the Environment of Norway, Oslo

Greenleaf J, Harmsen R, Angelini T, et al (2009) Analysis of impacts of climate change policies on energy security. 
Ecofys International BV, Utrecht

Hallegatte S, Przyluski V, Vogt-Schilb A (2011) Building world narratives for climate change impact , adaptation and vulnerability analyses. Nat Clim Chang 1:151-155 . doi: 10.1038/NCLIMATE1135

Harrison PA, Dunford RW, Holman IP, Rounsevell MDA (2016) Climate change impact modelling needs to include cross-sectoral interactions. Nat Clim Chang 6:885-890 . doi: 10.1038/nclimate3039

Harsem $\varnothing$, Eide A, Heen K (2011) Factors influencing future oil and gas prospects in the Arctic. Energy Policy 39:8037-8045 . doi: 10.1016/j.enpol.2011.09.058

Hollaway MJ, Arnold SR, Challinor AJ, Emberson LD (2012) Intercontinental trans-boundary contributions to ozoneinduced crop yield losses in the Northern Hemisphere. Biogeosciences 9:271-292 . doi: 10.5194/bg-9-271-2012

Huitema D, Adger WN, Berkhout F, et al (2016) The governance of adaptation: choices, reasons, and effects. Introduction to the special feature. Ecol Soc 21:37 . doi: 10.5751/ES-08797-210337

Hunt A, Watkiss P, Horrocks L (2009) International impacts of climate change on the UK. UK Department for Environment, Food and Rural Affairs (Defra), London

IEA (2013) Energy policies of IEA countries: Finland. International Energy Agency, Paris

IEA (2014) Energy Supply Security: Emergency Response of IEA Countries. International Energy Agency, Paris

IEA (2016) World Energy Outlook 2016. International Energy Agency, Paris

IEA (2017) Country statistics. http://www.iea.org/statistics/statisticssearch/. Accessed 13 Feb 2017

Kebede AS, Dunford R, Mokrech M, et al (2015) Direct and indirect impacts of climate and socio-economic change in Europe: a sensitivity analysis for key land- and water-based sectors. Clim Change 128:261-277 . doi: $10.1007 / \mathrm{s} 10584-014-1313-\mathrm{y}$

Khon VC, Mokhov II, Latif M, et al (2010) Perspectives of Northern Sea Route and Northwest Passage in the twentyfirst century. Clim Change 100:757-768 . doi: 10.1007/s10584-009-9683-2

King D, Schrag D, Dadi Z, et al (2015) Climate change risks to national and international security. In: Hynard J, Rodger T (eds) Climate Change: A Risk Assessment. Centre for Science and Policy, University of Cambridge, Cambridge, pp 120-129

Kissinger M, Rees WE (2010) An interregional ecological approach for modelling sustainability in a globalizing world Reviewing existing approaches and emerging directions. Ecol Modell 221:2615-2623 . doi: 10.1016/j.ecolmodel.2010.07.003

Larsen ER, Osorio S, van Ackere A (2017) A framework to evaluate security of supply in the electricity sector. Renew Sustain Energy Rev 79:646-655 . doi: 10.1017/CBO9781107415324.004

Lenschow A, Newig J, Challies E (2016) Globalization's limits to the environmental state? Integrating telecoupling into global environmental governance. Env Polit 21:136-159 . doi: 10.1080/09644016.2015.1074384

Li G, Sheng Y, Jin H, et al (2010) Development of freezing-thawing processes of foundation soils surrounding the China-Russia Crude Oil Pipeline in the permafrost areas under a warming climate. Cold Reg Sci Technol 64:226234 . doi: 10.1016/j.coldregions.2009.08.006

Lindholt L, Glomsrød S (2012) The Arctic: No big bonanza for the global petroleum industry. Energy Econ 34:14651474 . doi: 10.1016/j.eneco.2012.06.020

Liu J, Hull V, Batistella M, et al (2013) Framing sustainability in a telecoupled world. Ecol Soc 18:26 . doi: http://dx.doi.org/10.5751/ES-05873-180226

Liverman D (2016) U.S. National climate assessment gaps and research needs: overview, the economy and the international context. Clim Change 135:173-186 . doi: 10.1007/s10584-015-1464-5

Meyfroidt P, Lambin EF, Erb KH, Hertel TW (2013) Globalization of land use: Distant drivers of land change and geographic displacement of land use. Curr Opin Environ Sustain 5:438-444 . doi: 10.1016/j.cosust.2013.04.003

Mideksa TK, Kallbekken S (2010) The impact of climate change on the electricity market: A review. Energy Policy 38:3579-3585 . doi: 10.1016/j.enpol.2010.02.035

Ministry of Agriculture and Forestry (2014) Kansallinen ilmastonmuutokseen sopeutumissuunnitelma 2022. Ministry of Agriculture and Forestry of Finland, Helsinki 
Ministry of Employment and the Economy (2013) Kansallinen energia-ja ilmastostrategia. Ministry of Employment and the Economy of Finland, Helsinki

Moe A (2010) Russian and Norwegian petroleum strategies in the Barents Sea. Arct Rev Law Polit 1:225-248

Mohaddes K, Pesaran MH (2016) Country-specific oil supply shocks and the global economy: A counterfactual analysis. Energy Econ 59:382-399 . doi: 10.1016/j.eneco.2016.08.007

Moser SC, Hart JAF (2015) The long arm of climate change: societal teleconnections and the future of climate change impacts studies. Clim Change 129:13-26 . doi: 10.1007/s10584-015-1328-Z

Mulligan M (2015) Climate change and food-water supply from Africa's drylands: local impacts and teleconnections through global commodity flows. Int J Water Resour Dev 31:450-460 . doi: 10.1080/07900627.2015.1043046

Nelson FE, Anisimov OA, Shiklomanov NI (2002) Climate change and hazard zonation in the circum-Arctic permafrost regions. Nat Hazards 26:203-225 . doi: 10.1023/A:1015612918401

Norton T, Ryan M, Wang F (2015) Business Action for Climate-Resilient Supply Chains: A practical framework from identifying priorities to evaluating impacts. Business for Social Responsibility, San Francisco

Nærings- og fiskeridepartementet (2017) Norsk næringsvirksomhet - Strukturen i norsk økonomi. https://www.regjeringen.no/no/dokumenter/norsk-naringsvirksomhet---strukturen-i-n/id87547/. Accessed 7 Mar 2017

OECD/IEA (2016) Nordic Energy Technology Perspectives 2016. International Energy Agency and Nordic Council of Ministers, Paris and Copenhagen

OED (2012) Energiutredningen - verdiskaping, forsyningssikkerhet og miljø. Olje- og energidepartementet, Norge, Oslo

OED (2016) Kraft til endring: Energipolitikken mot 2030. Government of Norway, Oslo

Oppenheimer M (2013) Climate change impacts: Accounting for the human response. Clim Change 117:439-449 . doi: $10.1007 / \mathrm{s} 10584-012-0571-9$

Oppenheimer M, Campos M, Warren R, et al (2014) Emergent risks and key vulnerabilities. In: Field CB, Barros VR, Dokken DJ, et al. (eds) Climate Change 2014: Impacts, Adaptation, and Vulnerability. Part A: Global and Sectoral Aspects. Contribution of Working Group II to the Fifth Assessment Report of the Intergovernmental Panel on Climate Change. Cambridge University Press, Cambridge and New York, pp 1039-1099

Perdinan P, Winkler JA (2014) Changing human landscapes under a changing climate: Considerations for climate assessments. Environ Manage 53:42-54 . doi: 10.1007/s00267-013-0125-6

Rodríguez-Gómez N, Zaccarelli N, Bolado-Lavín R (2016) European ability to cope with a gas crisis. Comparison between 2009 and 2014. Energy Policy 97:461-474 . doi: 10.1016/j.enpol.2016.07.016

Schaeffer R, Szklo AS, Pereira de Lucena AF, et al (2012) Energy sector vulnerability to climate change: A review. Energy 38:1-12 . doi: 10.1016/j.energy.2011.11.056

Schenker O (2013) Exchanging goods and damages: The role of trade on the distribution of climate change costs. Environ Resour Econ 54:261-282 . doi: 10.1007/s10640-012-9593-Z

Scholten D, Bosman R (2016) The geopolitics of renewables; exploring the political implications of renewable energy systems. Technol Forecast Soc Change 103:273-283 . doi: 10.1016/j.techfore.2015.10.014

Seto KC, Reenberg A, Boone CG, et al (2012) Urban land teleconnections and sustainability. Proc Natl Acad Sci 109:7687-7692 . doi: 10.1073/pnas.1117622109

Stephenson SR, Smith LC, Agnew JA (2011) Divergent long-term trajectories of human access to the Arctic. Nat Clim Chang 1:156-160 . doi: 10.1038/nclimate1120

Streletskiy D, Anisimov O, Vasiliev A (2014) Permafrost degradation. In: Haeberli W, Whiteman C, Shroder Jr. JF (eds) Snow and Ice-Related Hazards, Risks, and Disasters. Elsevier Inc., Amsterdam, pp 303-344

Tarroja B, AghaKouchak A, Samuelsen S (2016) Quantifying climate change impacts on hydropower generation and implications on electric grid greenhouse gas emissions and operation. Energy 111:295-305 . doi: 10.1016/j.energy.2016.05.131

Task Force for Klimatilpasning (2012) Kortlægning af klimaforandringer: Muligheder og barrierer for handling. Government of Denmark, Copenhagen 
The Federal Government of Germany (2008) Worldwide adaptation - the German contribution. In: German Strategy for Adaptation to Climate Change. The Federal Government of Germany, Berlin, pp 51-53

Timmerman JG, Koeppel S, Bernardini F, Buntsma JJ (2011) Adaptation to climate change: Challenges for transboundary water management. In: The Economic, Social and Political Elements of Climate Change. SpringerVerlag, Berlin, pp 523-541

Tzanidakis K, Oxley T, Cockerill T, ApSimon H (2013) Illustrative national scale scenarios of environmental and human health impacts of Carbon Capture and Storage. Environ Int 56:48-64 . doi: 10.1016/j.envint.2013.03.007

Umbach F (2010) Global energy security and the implications for the EU. Energy Policy 38:1229-1240 . doi: 10.1016/j.enpol.2009.01.010

UN (2016) UN Comtrade Database. http://comtrade.un.org/data/. Accessed 18 Jul 2016

van Vliet MTH, Wiberg D, Leduc S, Riahi K (2016) Power-generation system vulnerability and adaptation to changes in climate and water resources. Nat Clim Chang 6:375-380 . doi: 10.1038/nclimate2903

Vlasova L V., Rakitina GS (2010) Natural risks management in the gas transmission system (GTS) of Russia and the contribution of climate services under global climate change. In: Troccoli A (ed) Management of Weather and Climate Risk in the Energy Industry. Springer, Dordrecht, pp 315-325

Ward DM (2013) The effect of weather on grid systems and the reliability of electricity supply. Clim Change 121:103113 . doi: 10.1007/s10584-013-0916-Z

Wilbanks T, Bilello D, Schmalzer D, Scott M (2014) Climate Change and Energy Supply and Use: Technical Report for the U.S. Department of Energy in Support of the National Climate Assessment. Island Press, Washington D.C.

Winkler JA, Thornsbury S, Artavia M, et al (2010) A conceptual framework for multi-regional climate change assessments for international market systems with long-term investments. Clim Change 103:445-470 . doi: 10.1007/s10584-009-9781-1

Ydersbond IM, Scholten D, Sattich T (2014) Power struggles: The geopolitical implications of EU energy policy. https://energiogklima.no/kommentar/power-struggles-the-geopolitical-implications-of-eu-energy-policy/. Accessed 22 Apr 2017

Yu Y, Feng K, Hubacek K (2013) Tele-connecting local consumption to global land use. Glob Environ Chang 23:11781186 . doi: 10.1016/j.gloenvcha.2013.04.006

Zakeri B, Virasjoki V, Syri S, et al (2016) Impact of Germany's energy transition on the Nordic power market: A market-based multi-region energy system model. Energy 115:1640-1662 . doi: 10.1016/j.energy.2016.07.083 